\title{
Effect of Computer-Use in Teaching on Acquisition of English Language Skills among Secondary School Students in Ife North Local Government Area of Osun State
}

\author{
Oribabor, O.A (Ph.D) \\ Institute of Education, Faculty of Education, Obafemi Awolowo University, lle-lfe \\ bisioribabor2006@yahoo.com
}

\section{Doi:10.5901/jesr.2014.v4n6p443}

\section{Abstract}

The paper examined the pattern of English language teaching in the secondary schools in Osun State. It also assessed the impact of the use of computer in teaching the subject on the acquisition of English language skills among students. A total of 150 students were involved in the study. This sample was drawn from three secondary schools in Ife North Local Government Area of the State in southwestern Nigeria. The schools were split into two groups with one group exposed to the use of computer as the experimental group and the other as the control group. An inventory to determine the effect of the computer use was employed to collect data. The study found out that the common pattern of English language teaching in secondary schools in Osun State was the conventional chalk and talk approach. It also found out that the use of computer in teaching English language brought significant improvement in students' learning of the subject. The study concluded that the use of computer in teaching provides an avenue to enhance students' learning of English language.

\section{Introduction}

English Language is a second language in Nigeria. It is a lingua franca which is used in ministries and parastatals; it is as well the medium of instruction is Nigerian schools. Suffice to say therefore that lack of adequate acquisition of the language is capable of negatively and significantly affecting students' learning and progress.

A number of interventions have been proffered to solve the problem of lack of proper knowledge of the English language. Some of these interventions have yielded positive results in some aspects of the subject; but which are still not sufficient to provide indicators that all is well. Technology has almost taken over all aspects of human life with computer especially dominating virtually everything we do. Human beings now have cause to interact with the computer almost every minute if not second. In a way, computer is diverting the attention of students from learning with all the services it is capable of offering. Experts are now exploring this popularity to improve teaching and learning. This is applicable to all subjects.

The introduction of ICT in the teaching of English is a new dimension in the acquisition of the language in Nigeria. English Language has contributed immensely to the development of Nigerian society politically, economically, socially and in all ramifications. One of the aspects of English Language that also in itself promotes acquisition of the language is reading. According to wilkpedia, "Reading is a complex cognitive process of decoding symbols in order to conduct or derive meaning. The overview of reading skills, is an assessment of cognitive benefits of reading of English acquisition. Today, computer is used in teaching reading.

A Computer is any electronic machine or device which is under the control of a stored programme, it can accept data in a prescribed form, process the data and supply the results as information in a specified format. A computer is simply a machine that is used to process data. Computer is an electronic machines, which processes data and supplies the result of processing and computer is contributed by some instructions called programmes given to it. These instructions are stored in the computer. Computers can be classified by type as Digital, Analogue, and Hybrid. This study was therefore designed to find out the influence of computer use in teaching on students' acquisition of English language reading skills.

\section{Purpose of the Study}

The purpose of this research is to examine the effect of ICT on students' acquisition of English language skills in some secondary schools in Ife North Local Government Area. The specific objectives of the study are therefore to 
(i) examine the pattern of teaching of English in Ife North.

(ii) assess the difference in the performance in the English language of students between those taught using computer and those that are not.

\section{Research Questions}

1. What is the common pattern in the teaching of English language in secondary schools in Osun State

2. What is the difference in the performance of students in English language between those that are taught using computer and those that are not.

\section{Significance of the Study}

The findings of the study will show to the students, teachers and general public in particular to the usefulness of ICT in learning English language. The study will also be beneficial to the students and the teachers by improving students' performance and thereby enhancing teacher productivity

\section{Delimitation of the Study}

This research is based on the effect of using computer to teaching on skills acquisition of students in English language. The study is limited to three selected schools in Ife North Local Government Area of Osun State. The study covered reading aspect of English language

\section{Methodology}

This portion of the paper discusses the vital aspects of research methodology which include population, sample, and instruments. It also discusses the techniques of data collection and analysis.

The population consisted of SS3 students in Ife North Local Government Area in Osun State in order to get reliable and accurate information on subject matter. Fifty students each were selected in Origbo Community, Origbo High School and C\&S Grammar School Edunabon in Ipetumodu, Moro and Edunabon towns of the local government area. The three schools were chosen based on nearness to each other. The schools were divided into two with computer used to teach in one group and the other school had teaching without the computer.

The intervention was made in the area of English Language basic grammar vocabularies, Oral English, Reading Comprehension, Essays, Summary and letter writing. Origbo community, Moro, Origbo High Schools Moro and Ipetumodu were given computers, to teach. A teacher is using computers to teach them English Language for three terms C\&S Edunabon were not given computer . Computers were not given to teachers to teach English Language to students for a session. They used textbooks on English as their sources of teaching.

\section{Results and Discussion}

The pretest conducted on the students before the intervention showed no difference in performance between students in the schools using computer to teach them English and those who did not.

Research question 1: what is the common pattern of teaching English language in secondary schools in Osun State.

Findings based on this question revealed that conventional chalk and talk approach was the common strategy used in the schools selected.

Research question 2: What is the difference in the performance of students in English language between those that are taught using computer and those that are not. 
Table 1: Summary of Observations after the Computer Intervention

\begin{tabular}{|l|l|l|}
\hline & \multicolumn{1}{|c|}{ School A using computers } & \multicolumn{1}{|c|}{ School B with no computers } \\
\hline 1 & They learnt faster in the acquisition of English & They learn English at a slow rate \\
\hline 2 & They had ability to read very well & The did not have ability to read well. \\
\hline 3 & Their level of spoken English had increased tremendously & Their level of spoken English was not impressive \\
\hline 4 & Computer corrected the students' mistake in Grammar & $\begin{array}{l}\text { Only the teachers corrected their mistakes, and made the } \\
\text { work tedious }\end{array}$ \\
\hline 5 & Students ability to learn English had increased & Students ability to learn English had decreased \\
\hline 6 & Students had the good knowledge of computers & Students did not have the good knowledge of computers \\
\hline 7 & Students could learn without teachers, & Students could only learn what the teacher teaching them \\
\hline 8 & $\begin{array}{l}\text { Their knowledge of English acquisition in vocabulary Essays, and } \\
\text { summarry had increase }\end{array}$ & $\begin{array}{l}\text { They had a vague knowledge of English in Vocabulary, } \\
\text { Essays and Summaries. }\end{array}$ \\
\hline
\end{tabular}

Results presented in table1 show the significant improvement that the use of computer in teaching English language has brought to students' learning in the subject. A further observation shows an analysis of the mistakes made by students who were not taught with the use of computer. Such mistakes were not made by students who were taught using the computer

Table 2: Mistakes made by students who were not exposed to computer but were corrected with the use of computer

\begin{tabular}{|l|l|l|}
\hline & Wrong & Correct \\
\hline 1 & Dontix & Don't \\
\hline 2 & 1go to the market yesterday & I went to the market yesterday \\
\hline 3 & We have go slow in the road & We have traffic jam on the road \\
\hline 4 & Lets settle the matter & Let's settle the matter. \\
\hline 5 & I loved the guy & I love the man. \\
\hline 6 & Where are u going & Where are you going \\
\hline 7 & Plese sit dow & Please sit down \\
\hline 8 & What is the mater with you & What is the matter with you? \\
\hline
\end{tabular}

Results show that the computers easily correct the wrong sentences freely for students to see and learn effectively and efficiently. With this it is possible for students learning English through the use of computers to learn it at a fast rate than student's who is being taught by teachers. In this situation, computer can correct million mistakes within a short time whereas teachers cannot do it. In this situation computers can now teach English effectively, than teachers of English.

\section{Conclusion}

From the findings, it is obvious to know that students that have computers to learn English learn at a faster rate than students without computers but solely relied on teachers. Therefore in an attempt to foster the study English in secondary schools, the government should not rely on teachers of English alone, but to extend the gestures to the use of computers to teach English acquisition which promote good mastery of English efficiently and effectively

\section{References}

Wilkpedia (1995). The free Encylopedia

Olatokun, W. (2007). Computer Studies for Secondary Schools

Ladan, R. T. (2001). Result based on the use of computer for English Language acquisition

Ayodele S. O. (2002). The use of English in Educating Nigerian youth from the problem to the solution. An inaugural lecture delivered at the University of Ibadan, Ibadan Power House Press and Publishers

Maguason, S . (2009). The uses of Computer in Teaching English for effectiveness and efficiency. London Publishers

Booz, A.(2009). The use of Biometric as a factor for learning English acquisition. In Biometric and Intelligent U.S.A : Boston Massarchussets

Bank S.O.T (2009) .The use of English acquisitions for teachers and Learners. London Publishers 
Kromant K. (2008). Computers world and the teaching of English as a learner in $2^{\text {nd }}$ language The classical computers publishing company: London.

\section{Appendix}

\section{Instructional to Respondents}

This questionnaire is to collect information on relevants of computers in English Language skill acqusition To Students:-
1. NAME:
2. School
3. Class
SS1 $\square$ SS2

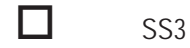
4. Sex
Male
female
5. Age
$13-15$
$15-17$
$17-22$

\section{Section B}

Complete this questionaire by putting a tick against the option that best describe your opinion - the opnion are A - agreed SA - stgrongly agreed D-disagreed SD - Strongly disagreed.

\begin{tabular}{|c|c|c|c|c|c|}
\hline $\mathrm{S} / \mathrm{N}$ & Item & SA & A & SD & $\mathrm{D}$ \\
\hline 1 & Computer is good for teaching English & 2 & 5 & 5 & 3 \\
\hline 2 & Teacher is better than computer in teaching English & 4 & 4 & 2 & 3 \\
\hline 3 & Computer is better than teachers in teaching English & 2 & 6 & 4 & 8 \\
\hline 4 & Using computer dissalow teacher to teach English very well & 3 & 4 & 1 & 2 \\
\hline 5 & Computer will create unemployment for english teachers & 2 & 4 & 05 & - \\
\hline 6 & Computers allow students to acquire the study of English faster & 1 & 6 & 3 & - \\
\hline 7 & Computers does not help students of English at all & 1 & & & 7 \\
\hline 8 & Computers has replaces teachers of English & 1 & 6 & & 1 \\
\hline 9 & Computers creates laziness for students of English & & 1 & & 7 \\
\hline 10 & Computers is a robot in the teaching of English & & 4 & & 4 \\
\hline 11 & Teachers teaches very well than computers & 1 & 3 & & 6 \\
\hline 12 & Teachers are more useful than computers & 1 & 2 & & 5 \\
\hline 13 & Computers corrects major errors in English & 1 & 1 & & 7 \\
\hline 14 & Teachers are useful than computers & 2 & 5 & 1 & 1 \\
\hline \multirow[t]{2}{*}{15} & Computers makes students computer literates & 1 & 1 & & 10 \\
\hline & & 20 & 65 & 12 & 71 \\
\hline
\end{tabular}

